\title{
The Relationship between Integrating Educational Technology in Mathematics Education and the Mathematics Achievement of German Students
}

\author{
Petronella Elize Saal ${ }^{1 *}$, Marien Alet Graham ${ }^{1}$, Linda van Ryneveld ${ }^{2}$ \\ ${ }^{1}$ Department of Science, Mathematics and Technology Education, University of Pretoria, Pretoria, SOUTH AFRICA \\ ${ }^{2}$ Comprehensive Online Education Services, University of Pretoria, Pretoria, SOUTH AFRICA
}

Received 20 March $2020 \cdot$ Accepted 10 August 2020

\begin{abstract}
The Education system in Germany recently invested five billion euro in digital infrastructure for about 40000 schools. Therefore, this mixed-method study explored the relationship between integrating educational technology in mathematics education and the mathematics achievement of Grade 4 German students. Descriptive statistics and two-level Hierarchical Linear Models (HLM) were used to analyse the Trends in Mathematics and Science Study (TIMSS) 2015 questionnaire data of students, their parents, mathematics teachers and principals. Semi-structured interviews and classroom observations were also used to collect data at two schools, which were conveniently and purposefully selected. Findings from HLM revealed that students who owned a mobile phone, a computer/tablet as well as those who used computers/tablets 'every or almost every day' at home, at school and other places for schoolwork, achieved lower mathematics scores than their counterparts. While the shared use of a computer/tablet and an internet connection positively and significantly predict student performances.
\end{abstract}

Keywords: educational technology, HLM, mathematics achievement, mathematics education, TIMSS 2015

\section{INTRODUCTION}

In 2016, the Bundesministerium für Bildung und Forschung (BMBF), also known as the German Federal Ministry of Education and Research, introduced the 'Bildung für die Digitale Wissensgesellschaft' (Bundesministerium für Bildung und Forschung [BMBF], 2016). One of the aims of this strategy was to identify and create opportunities for the digitalisation of all levels of schooling (BMBF, 2016). However, the president of the German Teachers' Federation, Mr. Josef Kraus, in an interview with Korbian Frenzel, stressed that "computers have no place in elementary schools" since digitalised lessons might hinder the learners' ability to concentrate (Kraus, 2015, p. 13; Kreijger, 2017). Similarly, Professor Manfred Spitzer, a German brain researcher explained in his book, Digitale Demenz, that digital media hinders the cognitive development skills of learners (Spitzer, 2012) thus, reducing their "learning and knowledge retention" (Spitzer, 2016, p. 1). The findings from the Programme for International Student Assessment (PISA) 2015 study also found no significant improvement in the learners' mathematics performance, especially in countries which made substantial capital investments towards educational technology (Organization for Economic Cooperation and Development [OECD], 2016).

Despite this, the previous German Minister of Education and Research, Johanna Wanka, proposed the Digital Pact program, aiming to provide digital infrastructure to about 40000 schools in Germany (Brady, 2016). In the light of this initiative, the Kultusministerkonferenz (KMK), also referred to as the Standing Conference of the Ministers of Education and Cultural Affairs, designed an action plan 'Bildung in der digitalen Welt, Strategie der Kultusministerkonferenz' that broadly recommends the use of educational technology in learning and teaching (Kultusministerkonferenz, 2016). Two of the objectives of this strategy is that teachers must be competent to use educational technology in their different learning areas and all learners must be competent to use educational technology by the year 2021 (KMK, 2016).

(c) $\mathbf{2 0 2 0}$ by the authors; licensee Modestum. This article is an open access article distributed under the terms and conditions of the Creative Commons Attribution License (http://creativecommons.org/licenses/by/4.0/).

$\square$ saal.pet@gmail.com (*Correspondence) $\square$ marien.graham@up.ac.za $\boldsymbol{\nabla}$ linda.vanryneveld@up.ac.za 


\section{Contribution to the literature}

- This mixed-method study adapted the comprehensive model of educational effectiveness created by Creemers (1994) to explore the relationship between integrating educational technology and the mathematics performance of Grade 4 students in Germany.

- The shared use of digital devices and the internet correlated positively with student performances, while, owning a mobile phone, a computer/tablet, as well as using a computer/tablet at home, school and other places correlated negatively with students' achievement.

- These findings caution against the frequent use of digital devices but support the shared use of these devices as well as the use of the internet for schoolwork purposes.

Regardless of these efforts made by the BMBF and KMK, it appears that the majority of German mathematics teachers still don't optimally use educational technology, due to the lack of support on how to use educational technology in the classroom, as well as a lack of digital infrastructure (Eickelmann, Lorenz, \& Endberg, 2016; Heinz, 2016). An expert on Computer-assisted learning (CAL) and mathematics, Professor Christian Spannagel, explained that these teachers are too stressed and do not have enough time to keep up with the developing technology (Üing, 2013). While Dagmar Missal from the Medienberatung (media advisory) in North Rine-Westphalia (a state in Germany) believes teachers are too "insecure and afraid of using the latest technology" (Üing, 2013, para. 15). The German teachers might also not have the needed skills to use educational technology in mathematics since only $18 \%$ attended professional development programmes focusing on the integration of Information Communication Technology (ICT) in instruction, which was below the 2013 International Computer and Information Literacy Study (ICILS) average of $43 \%$ (Eickelmann et al., 2016; Fraillon, Ainley, Schulz, Friedman, \& Gebhardt, 2014). This poor participating percentage could be a result of the fact that these teachers have to pay for the cost of professional development themselves since schools experienced budget cuts (Drossel \& Eickelmann, 2017).

\section{Rationale of the Study}

This study was conducted because of the low levels of educational technology integration by German mathematics teachers, as found in ICILS 2013. Merely 4\% of German learners reported that their mathematics teachers use computers during mathematics lessons, which placed Germany second last, only ahead of Norway, in ICILS 2013 (Fraillon et al., 2014). Moreover, the average performance of Grade 4 German learners decreased from 528 points in the Trends in Mathematics and Science Study (TIMSS) 2011 to 522 points in TIMSS 2015 (Mullis, Martin, Foy \& Hooper, 2016). In fact, the average score in TIMSS 2015 was below the average of 527 points for countries from the European Union (Wendt et al., 2016). What is of great concern is that merely $5 \%$ of these learners achieved more than 625 points. Meaning only a handful of German learners were ranked at the advanced international benchmark level, while $50 \%$ of the Grade 4 learners from Singapore performed at this advanced international benchmark level (Mullis et al., 2016).

Literature showed that a limited number of studies employed Hierarchical Linear Modelling (HLM) to explore the relationship between educational technology and the Grade 4 German learners' mathematics scores. For instance, Vennemann, Eickelmann and Wendt (2018) used the TIMSS 2015 data to investigate the use of ICT in elementary mathematics education in the Czech Republic, Germany and Denmark. The quantitative secondary data analysis of Vennemann et al.'s (2018) study did not include variables from the home background questionnaire. Consequently, this gap was filled by conducting a mixed-method study to explore the use of educational technology in mathematics education in German elementary schools. Data from TIMSS 2015 were used to investigate the relationship between using educational technology in mathematics and the mathematics achievement of Grade 4 learners in Germany. Variables from the school-, mathematics teacher-, learner- and home-questionnaires were included. Semi-structured face-to-face interviews with mathematics teachers and principals were also conducted to broaden the understanding of the quantitative findings. Additionally, the practices of educational technology during mathematics lessons were also observed.

\section{Research Questions}

The following research questions guided this study:

- For what purposes and how frequently do German Grade 4 learners, as well as their mathematics teachers, use educational technology in mathematics education?

- How do German mathematics teachers perceive the support available for using educational technology in mathematics teaching and learning?

- What, if any, are the hindering and supporting factors influencing these teachers' integration of educational technology in mathematics? 
- How is the integration of educational technology in mathematics education related to the Grade 4 learners' mathematics achievement?

\section{LITERATURE REVIEW}

A large volume of studies investigated the relationship between educational technology and the mathematics achievement of learners, using data mostly from large scale studies such as TIMSS (Ayieko, Gokbel, \& Nelson, 2017; Kruger, 2018) and PISA (Comi, Argentin, Gui, Origo, \& Pagani, 2017; Kim, 2018; Zhang \& Liu, 2016). Nevertheless, findings on the relationship between using educational technology in mathematics education and learners' achievement have been inconsistent. Researchers have found both statistically significant positive relationships (Eickelmann, Drossel, Wendt, \& Bos, 2012; Falck, Mang, \& Woessmann, 2018; Visser, Juan, \& Feza, 2015) and statistically significant negative relationships (Bulut \& Cutumisu, 2017; Comi et al., 2017; Hu, Gong, Lai, \& Leung, 2018) between educational technology and learner performances.

\section{Statistically Significant Negative Relationships between Using Educational Technology and Learner Achievement}

Researchers such as Bulut and Cutumisu (2017) used Structural Equation Modelling (SEM) to determine the relationship between Information Communication Technologies (ICTs) and the mathematics achievement of Finnish and Turkish learners who participated in PISA 2012. One of their findings showed a significant negative relationship between using ICTs at school in both countries. This finding is in line with the results of Hu et al. (2018), Comi et al. (2017) as well as Güzeller and Akin (2014) who also found that educational technology negatively influences the mathematics achievement of learners who participated in PISA 2015 and 2006, respectively.

Studies conducted by Kruger (2018), Kadijevich (2015) and Skryabin, Zhang, Liu, and Zhang (2015) based on datasets from TIMSS 2011 and 2015, also found that the frequent use educational technology by learners at school resulted in lower mathematics scores. In their study, Eickelmann et al. (2017) attempted to explain the negative relationship by saying that learners with poor mathematics results use educational technology more frequently in an attempt to improve their results. Whereas, Zuzovsky (2013) argues that this relationship is negative because learners tend to focus more on educational technology, which diverts their attention from the mathematics content. Other researchers also found that the availability of educational technology at home also correlated negatively with the learners' mathematics achievement (Hu et al., 2018; Kruger, 2018).
Statistically Significant Positive Relationships between Using Educational Technology and Learner Achievement

Eickelmann et al. (2012) used data from TIMSS 2007 to investigate the elementary school learners' use of computers and their mathematics achievement in Germany, Singapore and Australia. Some of their findings showed a statistically significant positive relationship when German and Singaporean learners used computers at their homes. Conversely, the use of computers at school only showed a statistically significant positive relationship in Australia and Singapore. This is in line with another finding from Bulut and Cutumisu (2017) indicating that the availability of ICT at home, as well as at school, resulted in a significant improvement of the mathematics achievement of learners in Turkey. One of the findings from a study based on PISA 2012 by Petko, Cantieni, and Prasse (2017), similarly showed a significant positive relationship when digital technologies are used at home for school-related purposes.

Some researchers also found statistically significant positive relationships between using educational technology for certain activities in mathematics and learner achievement. For example, Falck et al. (2018) found a positive relationship when Grade 4 learners, who participated in TIMSS 2011, used computers to look up ideas and information during mathematics lessons. Researchers, such as (Visser et al., 2015), also used the TIMSS 2011 dataset for South Africa and found that learners' scores predicted positively when computer software was used as basis or to supplement instruction during mathematics lessons. Similarly, Meggiolaro (2018) used the PISA 2012 dataset of Italy to investigate the significance of ICTs in mathematics attainment while controlling for gender. Findings showed that boys achieved higher mathematics results when they used ICTs for gaming as well as for information management and technical operations, which stimulated their strategic thinking and problem-solving skills (Meggiolaro, 2018). A positive relationship between computer usage in mathematics classes and mathematics achievement in Belgium, Denmark, as well as Norway was also found in PISA 2015, especially when variables such as the socioeconomic status of the school and learners were controlled for (OECD, 2016).

The preceding discussion clearly indicates that there is still much debate regarding the relationship between using educational technology in mathematics education and learner performances. Existing literature to date has focussed more on aggregate relationships, rather than explaining the reasons why such relationships exist in the first instance. Reasons for these relationships when revealed have been sometimes offered, but not well integrated into the actual analyses. Most of the literature is also based on quantitative secondary data analysis which means that several limitations could have 


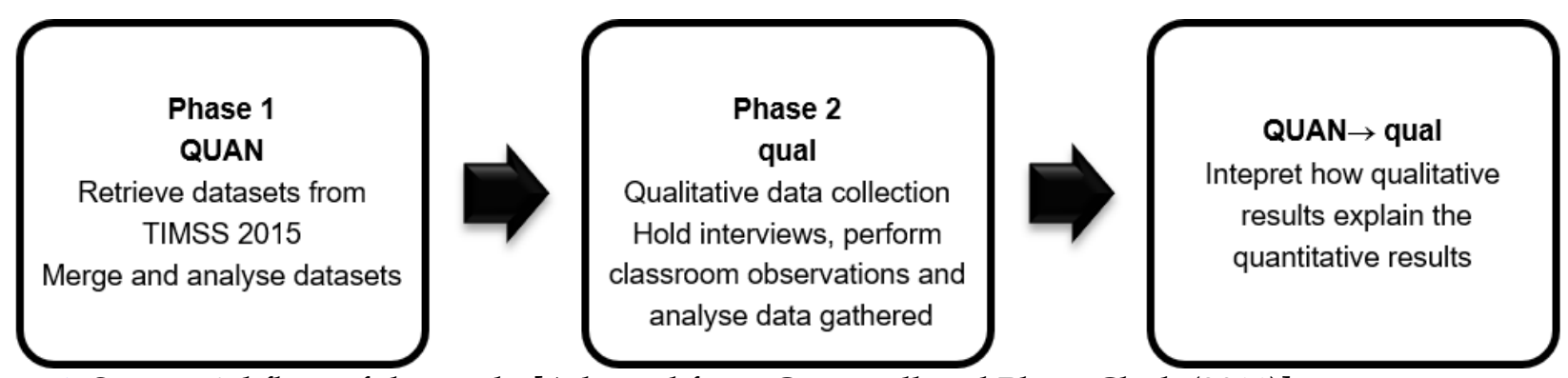

Figure 1. Sequential flow of the study [Adapted from Cresswell and Plano Clark (2011)]

influenced the findings of these type of studies. For instance, findings, could have been constrained by the limitations of the original research. These limitations could have included; possible sources of error, data being limited to the original number of respondents and the profile of the sample (Boslaugh, 2007). This indicates the need for more mixed-method studies to try and justify the relationships amongst variables in question. It is therefore clear that there is not yet a definitive answer to whether there is an association amongst the integration of educational technology in mathematics teaching and learning and learner performances since results at the national level have been inconsistent as such, there is a need for this study.

\section{METHOD}

An explanatory sequential mixed method design was followed to investigate the relationship between using educational technology (independent variables) in mathematics and the mathematics achievement (dependent variable) of Grade 4 learners. The explanatory sequential mixed method design was employed because qualitative data were collected after the quantitative phase was completed. More specifically, the National Research Coordinators (NRCs) of each country collected the quantitative data in 2015, and the qualitative data were gathered by the researcher in 2018 . The quantitative phase thus provided the context in which the qualitative data collection was undertaken. The qualitative phase was needed to contextualise the results of the quantitative phase, to address research questions which were not answered by TIMSS data and to offer another lens on the data. The sequential nature of this design also allowed for follow-up questions during the qualitative phase, which explained some of the findings which were unclear during the quantitative phase. Figure 1 illustrates the sequential flow of the quantitative and qualitative phases of this study.

\section{Participants}

For the quantitative phase, the Grade 4 mathematics dataset of Germany from TIMSS 2015 was used (International Association for the Evaluation of Educational Achievement [IEA], 2019). The latter used a stratified two-stage cluster sample design (LaRoche,
Joncas \& Foy, 2016). Firstly, schools were sampled according to their size (Johansone, 2016). Thereafter, these schools were stratified according to certain characteristics. For example, 17901 schools in Germany were eligible, but only 204 schools were included in the sample, which was stratified based on immigration status and school type (LaRoche et al., 2016). Thirdly, intact classes were sampled to "ensure that the sample of classes results in a representative sample of learners, and every learner at the target grade has a chance of being selected" (Johansone, 2016, p.6). A total of 3948 Grade 4 learners, 224 mathematics teachers, 2470 parents or guardians, as well as 184 principals participated in TIMSS 2015 (Wendt et al., 2016).

Data for the qualitative phase was collected through multiple explanatory case studies. The purpose was to gain a deeper understanding of teachers' current use of educational technology in mathematics education and also to gather their opinions on the quantitative findings of this study. Convenient and purposive sampling methods were used to select mathematics teachers from two multi-racial elementary schools in the rural area of Northrine-Westfalia, Germany. These schools accommodate around 200 to 250 learners, respectively, and are managed by female principals.

\section{Data Collection and Instruments}

The data collection for TIMSS 2015 in Germany took place from March 2015 to May 2015 (Johansone, 2016). In this study, certain questions from the school-, mathematics teacher-, learner- and home-background questionnaires, as well as the learners' mathematics achievement scores were used. The TIMSS 2015 developers designed 14 achievement booklets consisting of 14 mathematics and 14 science items (LaRoche et al., 2016). A systematic procedure was used to assign a booklet which consisted of 14 mathematics and 14 science blocks to each learner which they had to complete within 36 minutes. The learners received a 30minute interval between blocks (Johansone, 2016).

Focussing on the qualitative phase, semi-structured interviews, as well as non-participatory classroom observations, took place in January 2019 and March 2019. Interviews ranging between 30 to 60 minutes were conducted with one principal (who also taught Grade 4 mathematics) and two Grade 4 mathematics teachers. 
Table 1. Summary of learner and school variables

\begin{tabular}{|c|c|c|}
\hline Directory & Variable & Variable explanation \\
\hline \multicolumn{3}{|l|}{ School-level predictors (level-2) } \\
\hline \multirow{13}{*}{$\begin{array}{l}\text { Reported by mathematics } \\
\text { teacher }\end{array}$} & ATBG01 & Teaching experience \\
\hline & ATBG02 & Teachers gender \\
\hline & ATBG03 & Teachers age \\
\hline & ATBG08F & Adequate technological resources \\
\hline & ATBG08G & Adequate support for using educational technology \\
\hline & ATBM05A & Availability of computers/tablets in mathematics classes \\
\hline & ATBM05BA & Every learner has his/her own computer in the classroom \\
\hline & ATBM05BB & There are computers in the classroom that learners can share \\
\hline & ATBM05BC & The school has computers that the class can use \\
\hline & ATBM05CA & Computers to practise skills and procedures \\
\hline & ATBM05CB & Using computers to explore principals and concepts \\
\hline & ATBM05CC & Using computers to look up ideas \\
\hline & ATBM09D & Professional development for using IT in mathematics \\
\hline \multirow[t]{7}{*}{ Reported by principal } & ACBG03A & Economically disadvantaged homes \\
\hline & ACBG03B & Economically affluent homes \\
\hline & ACBG14AF & Technologically competent staff \\
\hline & ACBG14AG & Audio-visual assets for teaching and learning \\
\hline & ACBG14AH & Computer technology for teaching and learning \\
\hline & ACBG14BA & Shortage of teachers who specialised in mathematics \\
\hline & ACBG14BB & Computer software for mathematics instruction \\
\hline \multicolumn{3}{|c|}{ Learner-level predictors (Level-1) } \\
\hline \multirow[t]{8}{*}{ Reported by learner } & ASBG01 & The gender of the learners \\
\hline & ASBG05A & The learner own computer/tablet \\
\hline & ASBG05B & Shared computer/tablet with other people at home \\
\hline & ASBG05E & Internet connection \\
\hline & ASBG05F & Own mobile phone \\
\hline & ASBG10A & Using computer or tablet at their homes for schoolwork \\
\hline & ASBG10B & Using computer or tablet at school for schoolwork \\
\hline & ASBG10C & Using a computer or tablet at other places for schoolwork \\
\hline Reported by parent or guardian & ASBH15 & Digital devices at home \\
\hline Learners mathematics scores & $\begin{array}{l}\text { ASMMAT01 to } \\
\text { ASMMAT05 }\end{array}$ & 1st to 5 th plausible value mathematics \\
\hline
\end{tabular}

These interviews were digitally recorded. Additionally, one mathematics lesson, from a fourth mathematics teacher, who was not interviewed, was observed. The interview schedule for mathematics teachers and principals was piloted before doing the actual interviews to ensure that these instruments measure what they were supposed to measure. The credibility of the study was further enhanced by including follow-up and probing questions in the interview protocol.

\section{Data Analysis}

For the quantitative phase of this study, both descriptive and inferential statistics were employed to analyse data obtained from TIMSS 2015. The International Database Analyzer (IDB Analyzer) version 4.0 was used to obtain descriptive statistics that included percentages and means. For inferential statistics, the HLM version 7 statistical program was used to perform a two-level HLM analysis considering the hierarchical structure of the TIMSS 2015 data. Table 1 outlines the variables used in this phase.
Focussing on the qualitative phase, the audio recordings were transcribed verbatim. The data was coded as follows: the first school where interviews were conducted was coded as SchDEU1 and the second school was coded as SchDEU2, the female principal from SchDEU1=FP_SchDEU1, the female teacher from SchDEU1 = FT_SchDEU1, the male teacher from SchDEU1= MT_SchDEU1 and the male teacher from SchDEU2 was MT_SchDEU2. Directed content analysis was used by searching for pre-setting, as well as new codes derived from the data (Hsieh \& Shannon, 2005).

\section{RESULTS AND DISCUSSION}

In this section, the use of educational technology by Grade 4 German learners and their mathematics teachers are explained. Thereafter, the teachers' perceptions regarding the extent to which they receive support from the school are explained. The hindering and supporting factors that influence the integration of educational technology are also discussed, followed by two-level HLM of the relationships between using educational 
Table 2. Extent of computer/tablet usage at home, school and other places for mathematics schoolwork and the learners' average mathematics performance

\begin{tabular}{lcccc}
\hline & \multicolumn{3}{c}{ Never or } & \multicolumn{3}{c}{ Once or twice a Once or twice a Every or almost } \\
& almost never & month & week & every day \\
\hline Percentage (average) & & & & \\
\hline Computers for mathematics schoolwork at home & $34.31(536.69)$ & $14.00(542.89)$ & $21.63(527.12)$ & $30.07(508.62)$ \\
Computers for mathematics schoolwork at school & $75.60(536.30)$ & $9.47(531.61)$ & $8.48(523.37)$ & $6.45(489.66)$ \\
Computers for mathematics schoolwork at other places & $63.72(538.26)$ & $11.23(534.79)$ & $14.78(518)$ & $10.27(498.46)$ \\
\hline
\end{tabular}

Table 3. Extent of computer usage for selected mathematics tasks by learners as well as their average mathematics performance

\begin{tabular}{|c|c|c|c|c|}
\hline & $\begin{array}{c}\text { Never or } \\
\text { almost never }\end{array}$ & $\begin{array}{c}\text { Once or twice a } \\
\text { month }\end{array}$ & $\begin{array}{c}\text { Once or twice a } \\
\text { week }\end{array}$ & $\begin{array}{c}\text { Every or almost } \\
\text { every day }\end{array}$ \\
\hline \multicolumn{5}{|l|}{ Percentage (average) } \\
\hline Look up ideas on the computer & $48.42(516.81)$ & $35.06(516.89)$ & $15.45(531.42)$ & $1.06(535.42)$ \\
\hline Practice skills and procedures on the computer & $23.32(516.13)$ & $51.21(517.11)$ & $22.70(522.22)$ & $2.77(533.50)$ \\
\hline Explore concepts on the computer & $59.28(520.54)$ & $26.78(512.76)$ & $12.95(520.87)$ & $0.99(551.27)$ \\
\hline
\end{tabular}

technology in mathematics education at school and learner-level, and the mathematics achievement of learners.

\section{Purpose and Frequency with which German Learners Used Educational Technology in Mathematics Education}

Learners reported that they use computers for mathematics schoolwork at home, school, as well as other places as illustrated in Table 2.

Most learners (30.07\%) used computers/tablets 'every or almost every day' at home for mathematics schoolwork. This could be because the majority of learners indicated that they 'never or almost never' used computers at school $(75.60 \%)$ or other places $(63.72 \%)$ for schoolwork. An interesting observation is that the learners who 'never or almost never' used computers at home, school and other places received higher mathematics averages than the learners who used computers 'every or almost every day' at home, school and other places.

\section{Purpose and Frequency with which German Mathematics Teachers Supported Learners to Use Educational Technology in Mathematics Education}

The findings showed that learners were taught by teachers who supported them to use computers to look up ideas, to practise skills and procedures, as well as to explore mathematical concepts on the computer (see Table 3).

The results revealed that for every selected mathematics task, fewer than $3 \%$ of the learners were taught by teachers who supported them to use computers 'every, or almost every, day' in their classroom instruction to look up ideas, to practice skills and procedures or to explore concepts in mathematics. These learners achieved higher mathematics scores than the learners who were taught by teachers who 'never, or almost, never' used computers to look up ideas, to practice skills and procedures or to explore concepts in mathematics (see Table 3).

\section{Purpose and Frequency with which German Teachers Used Educational Technology in Mathematics Education}

The preceding discussion shows that very few teachers supported their learners to use computers in mathematics education. It was thus no surprise when the qualitative data revealed that very few teachers use computers in mathematics education. For instance, FT_SchDEU1 explained that very few teachers use educational technology in mathematics, because there are simply not enough computers. FP_SchDEU1 explained that the lack of computers is mostly due to a lack of finances. Consequently, teachers have to take their learners in small groups to the computer room once a week to support lessons for stronger and weaker learners (FP_SchDEU1).

Only nine boxes of LEGO Education WeDo 2.0 programming software that learners could use, was noted during the classroom observation. In this lesson, MT_SchDEU1 demonstrated how to construct a snail with Legos. This step by step programming process engaged the learners and required them to use their critical thinking and problem-solving skills to complete this project. MT_SchDEU1 explained that "only the stronger learners get the opportunity to program certain models" due to the limited number of tablets and LEGO Education WeDo 2.0 programming software licenses. Findings also showed that most participants used educational technology as a motivational and as a supplemental teaching tool. For instance, FP_SchDEU1 explained: "Computers can be a good supplement for teaching when learners need to practise mathematical skills and to provide individual feedback". MT_SchDEU2 also said: "I mostly used software to explain mathematics operations. I think computers are mostly a 
motivational tool and it is also kind of handy for additional activities when learners are done with their work".

\section{Teachers' Perceptions Regarding the Use of Educational Technology Mathematics Education}

Interviews also showed that all the participants were very excited about the idea of using educational technology in mathematics instruction and acknowledged the advantages for learners and teachers when using these devices. FT_SchDEU1 and FP_SchDEU1 believed, however, that using educational technology in mathematics teaching and learning won't necessarily improve the performance of learners. FT_SchDEU1 clarified: "I don't think educational technology alone can improve learner performances because in some areas of the mathematics curriculum for instance, geometry, learners are required to do things with their hand". Whereas FP_SchDEU1 argued that:

The computer doesn't improve learner performances, it just motivates them. It is a good supplement for teaching, but it should not be used frequently because it decreases the learners' motivation to work with computers. It is also important especially for primary school children to touch things and to use all senses for learning and that sometimes cannot be done by a computer.

On the other hand, MT_SchDEU2 believed that educational technology might improve learner performances in mathematics because the learners get motivated to work, and "they want to learn because it is on a smartphone..." He was also of the opinion that educational technology improved the problem-solving skills of learners, but FT_SchDEU1 and FP_SchDEU1 disagreed, as shown in the comments below:

"Educational technology doesn't improve learners" problem-skills in mathematics, but instead just motivate learners to do mathematics... They don't understand mathematical problems easier with a computer. They just like to work the computer, it's something special". (FT_SchDEU1)

"Educational technology doesn't improve learners' problem-solving skills. It is only helpful to give learners individual feedback". (FP_SchDEU1)

All the participants also believed that educational technology provides a good platform for teachers to communicate with each other and with the parents. These participants used their smartphones (WhatsApp) and emails to communicate with each other. They also indicated that they sometimes used the school's website to communicate with parents. Similarly, all participants believed that the traditional way of teaching is more effective than using technology. For instance, FT_SchDEU1 said: "The traditional way of teaching is better than using educational technology, because maths is sometimes very complicated to use a computer". Equally,
FP_SchDEU1 explained: "Educational technology complements the traditional methods of teaching, but I cannot say that it is better than the traditional method". Likewise, MT_SchDEU2 argued:

The technology-assisted instruction is not more effected than the traditional teaching methods, because mathematics is not just on a computer, it is all around you. Learners need to explore the world. For learners to really learn they need to be outside.

Similarly, all teachers believed that computers would not replace teachers because "learners need social contact" (FT_SchDEU1) and "a person to have a relationship with to support learning" (FP_SchDEU1).

\section{Teachers' Perceptions Regarding the Support for Using Educational Technology Mathematics Education}

Findings from the interviews showed that teachers mostly rely on the support of their colleagues to assist them when technical problems occurred while using educational technology during mathematics lessons. One setback was that the male colleague, who is technologically competent according to the principal, was teaching most of the times and was sometimes not available to assist due to his own teaching responsibilities. FP_SchDEU1 explained that she gave the male colleague one teaching period less for him to assist the other teachers. At the other school, MT_SchDEU2 explained that he assisted the teachers by compiling a media concept consisting of the available educational technology at the school, their purposes, and how to use it.

\section{Hindering Factors that Influenced Mathematics Teachers' Integration of Educational Technology}

For teachers to use educational technology in mathematics education they need to have access to the physical devices. Teachers at SchDEU1 had limited use of educational technology at their school because of the lack of funding opportunities from their government. For instance, this school only had eight tablets, as mentioned earlier, and learners had shared access to the computer room once a week. SchDEU1 had two computers per classroom that roughly 30 learners had to share. The next quotes highlight the need for educational technology:

- I think it is better when every learner in the class can have a tablet and that there are at least two computers in the classrooms. (FP_SchDEU1)

- I don't use a computer in the classroom, because we don't have computers in the classroom. It would be good to have a computer in the classroom for learners, or tablets for every learner. (FT_SchDEU1) 
Table 4. The significant predictors for the parsimonious model

\begin{tabular}{|c|c|c|c|c|}
\hline Variable & Coefficient & Standard error & t-value & p-value \\
\hline \multicolumn{5}{|l|}{ School and teacher (level-2) } \\
\hline Economically disadvantaged homes & 16.27 & 2.59 & -6.28 & $0.000^{*}$ \\
\hline \multicolumn{5}{|l|}{ Learner and home variables (Level-1) } \\
\hline Learners gender & -8.40 & 3.06 & 2.73 & $0.008^{*}$ \\
\hline Learner own a computer/tablet & -8.29 & 3.65 & 2.27 & $0.039 *$ \\
\hline Share Computer/tablet with others at home & 15.38 & 2.65 & -5.79 & $0.000^{*}$ \\
\hline Internet connection & 24.36 & 3.51 & -6.92 & $0.000^{*}$ \\
\hline Owning a mobile phone & -22.63 & 3.61 & 6.26 & $0.000^{*}$ \\
\hline Computers for schoolwork at home & -3.80 & 1.16 & 3.26 & $0.001^{*}$ \\
\hline Computers for schoolwork at school & -12.26 & 1.90 & 6.43 & $0.000^{*}$ \\
\hline Computers for schoolwork at other places & -8.00 & 1.56 & 5.11 & $0.000^{*}$ \\
\hline Digital devices at home & -11.66 & 2.25 & 5.17 & $0.000^{*}$ \\
\hline
\end{tabular}

* Significant at a 5\% level of significance

- I don't think we have enough technologies. The computer room is also used for other projects so I can't always use this room. (MT_SchDEU2)

MT_SchDEU2 also emphasised the need for continuous professional development that can be transferred to the mathematics classroom since he could not apply anything that he learned at a training session in his classroom. FT_SchDEU1 also stressed the need for continuous professional development, since technology is always evolving. She explained: "I would like to receive training on how to use the whiteboard. Training should also occur when new devices get to the school and when something is developing with these devices". (FT_SchDEU1)

All the participants expressed the need for an IT technician that is stationed at the school. For instance, FP_SchDEU1 explained that the IT technician is situated at the city hall and is responsible for almost 50 schools in the region. At SchDEU2, a different IT technician who is not situated at the city hall, have to be called several times "due to his forgetfulness" as explained by MT_SchDEU2.

\section{Factors that Facilitated the Mathematics Teachers' Integration of Educational Technology}

All the participants indicated that they have a reliable internet connection at the school, which assisted the teachers in searching for resources to incorporate in teaching and learning. MT_SchDEU2 explained that the school has mathematics software and access to his technical skills that could be used to facilitate the integration of educational technology in mathematics teaching and learning. Lastly, FT_SchDEU1 and FT_SchDEU1 both explained that the security measures that are in place when learners explore the internet, assisted them to control the learning environment.

\section{The Relationship between Integrating Educational Technology in Mathematics Education and Learner Achievements}

HLM was used to determine the relationship between using educational technology in mathematics education and learner achievements. Three HLM analyses were created. Initially, the null model without any variables was created, the full model with all the variables (see Appendix A) and the parsimonious model (see Table 4). Table 4 illustrates the significance level, as well as coefficients for the parsimonious model.

The findings showed that learners who were registered at schools which housed 'fewer than $10 \%$ ' of learners from economically disadvantaged homes $(\beta=$ 16.27 , p-value $<0.001)$, outperformed learners registered at schools that accommodated 'more than 50\%' of learners from economically disadvantaged homes. This could be because learners enrolled at schools that accommodate mostly economically disadvantaged homes lack stimulation in the living environment outside of school, rather than cognitive abilities, as FP_SchDEU1 explained. This finding supports the results from PISA 2015 which showed that learners from economically disadvantaged homes in Germany, scored 42 points lower than their counterparts, which was 8 points higher than the OECD average (OECD, 2016).

The results also indicated that girls $(\beta=-8.40$, $p$-value $=0.008$ ) scored lower mathematics results than boys. This finding is on par with the results of PISA 2015, where boys from Germany outperformed girls with a 17 points difference (OECD, 2016). Similar results emerged from the findings of Anjum (2015) showing that boys outperformed girls in a national mathematics test developed by the National Council for Educational Research in India. This could be due to gender stereotyping; for instance, "Boys are good in mathematics and girls are good in languages" as explained by MT_SchDEU2 4.

Likewise, learners who owned a computer/tablet $(\beta=$ -8.29, $\mathrm{p}$-value $=0.039$ ) were outperformed by learners who did not own a computer/tablet. This finding corroborates the results of Geesa, Izci, Song, and Chen (2019) showing that Grade 4 Korean and Turkish learners who owned a computer/tablet, performed worse in mathematics than learners who did not own these devices. A possible reason for this could be that 
these learners used these devices for non-mathematics related purposes, such as communication and entertainment, as explained by FP_SchDEU1.

On the other hand, learners who had shared use of a computer/tablet with people at their homes $(\beta=15.38$, $\mathrm{p}$ value $<0.001)$, outperformed learners who did not share a computer/tablet with others. This finding also verifies the results of Geesa et al. (2019) indicating that learners from Korea, Turkey and the United States who shared a compute/tablet, had better mathematics results than learners who did not share these devices. This indicates that learners perhaps did not have a lot of time to use the devices because they shared it with other people (MT_SchDEU2).

Similarly, learners who had an internet connection at home $(\beta=24.36$, $p$-value $<0.001)$ outperformed learners without a home internet connection. Positive relationships between internet availability at home and mathematics achievement were also evident in Korea, Turkey and the United States Geesa et al. (2019) as well as in South Africa Kruger (2018). This could be explained by the fact that the internet, if it is used wisely, can help learners to get information for research-related tasks that require strategic competencies that may also foster mathematical thinking as expressed by FP_SchDEU1 and Skryabin et al. (2015).

In contrast with Ariyanto, Kusumaningsih, and Aini (2018) who found that mobile phones positively correlated with the mathematics achievement of learners in Indonesia, this study found that learners who owned a mobile phone $(\beta=-22.63$, $p$-value $<0.001)$ achieved lower mathematics scores than learners who did not own a mobile phone. This could be because mobile phones distracted learners from concentrating on the schoolwork, as pointed out by $\mathrm{Xu}$ (2015) as well as Topçu, Erbilgin, and Arikan (2016).

Additionally, learners that used computers or tablets 'every or almost every day' at home $(\beta=-3.80, p$-value $=$ $0.001)$, at school $(\beta=-12.26$, $p$-value $<0.001)$, as well as other places $(\beta=-8.00, p$-value $<0.001)$ for schoolwork, were outperformed by learners who 'never or almost never' used computers or tablets at those places. Similarly, Kruger (2018) supports this finding indicating that the regular use of computers by South African learners at their homes, schools and at other places resulted in lower mathematics performance. A possible explanation for this could be that at a Grade 4 level an intensive teacher-learner interaction is required to understand mathematical concepts, as well as to develop higher-order thinking skills (OECD, 2014). FP_SchDEU1 explained that this teacher-learner interaction is sometimes not possible when computers are available since learners tend to focus more on computers.

Lastly, focussing on the number of digital devices at home, results showed that learners who reported to having 'more than 10 ' digital devices at home $(\beta=-11.66$, p-value < 0.001) were more likely to have lower results than learners with no digital devices at their homes. A possible reason for this might be that learners with more digital devices use it mostly for social media and games, and not necessarily for mathematics-related tasks, as MT_SchDEU2 clarified.

Based on the preceding results, a statistically significant relationship was found between integrating educational technology in mathematics education and learner achievement.

\section{CONCLUSION}

This study investigated the relationship between integrating educational technology in mathematics and the Grade 4 German learners' mathematics performance. More than $75 \%$ of these learners 'never or almost never' use educational technologies at school. Furthermore, for every mathematics task, fewer than 3\% of these learners were taught by teachers who let them use computers 'every or almost every day' to search for information, to practise their mathematics skills, as well as to explore procedures and concepts during mathematics lessons. Surprisingly, some of these teachers used computers and software as a motivational and supplement- teaching tool to improve the learners' problem solving and critical thinking skills. Results also showed that learners with 'more than 10' digital devices, learners who own computers/tablets or mobile phones, as well as those who use computers/tablets 'every or almost every day' at school, home and other places, achieved lower mathematics scores than their counterparts.

Surprisingly, learners who shared computers/tablets, as well as those with an internet connection, achieved higher mathematics results, than their counterparts. Findings indicated that a reliable internet connection, technically skilled teachers and having solid security measures in place when learners use computers, facilitates the integration of educational technology in mathematics education. Furthermore, for teachers to optimally use educational technology in mathematics the barriers, such as lack of computers and tablets, lack of qualified IT technicians, as well as lack of continuous professional development that hinders their integration of educational technology in mathematics education, need to be addressed.

This study was limited to the TIMSS 2015 Grade 4 dataset of Germany, as well as inputs from four mathematics teachers from two schools in NorthrineWestfalia. Future researchers could use more schools, perhaps one in every state of Germany, to determine why the use of educational technology learner-level influenced learner achievement, while no statistically significant relationship was found at the school-level. The findings of this study caution against the frequent use of digital devices at home, school and other places and supports the use of the internet for school-related 
tasks. This study contributes to the literature on educational technology integration in mathematics education.

\section{ACKNOWLEDGEMENTS}

The authors would like to thank Prof Melanie Platz and Prof Ingo Witzke for their assistance during the data collection process.

Petronella Saal's research was funded by the [Deutscher Akademischer Austausch Dienst and National Research Foundation (NRF)] under Grant number [DAAD160728182965] and the [University of Pretoria].

Marien Graham's research was funded by the NRF [Reference: CSRP190415430728, Grant number: 120401].

\section{REFERENCES}

Anjum, S. (2015). Gender difference in mathematics achievement and its relation with reading comprehension of children at upper primary stage. Journal of Education and Practice, 6(16), 71-75. https:/ / files.eric.ed.gov/fulltext/EJ1079951.pdf

Ariyanto, L., Kusumaningsih, W., \& Aini, A. N. (2018). Mobile phone application for mathematics learning. In N. Hidayat, M. Rasiman, S. Novita, A. Handayani, A. Buchori (Eds.). Paper presented at the Proceedings of the 1st International Conference on Education and Social Science Research (ICESRE 2018). Journal of Physics: Conference Series (Vol. 983, No. 1, p. 012106). IOP Publishing. https://doi.org/10.1088/1742-6596/983/1/012106

Ayieko, R. A., Gokbel, E. N., \& Nelson, B. (2017). Does computer use matter? The influence of computer usage on eighth-grade students' mathematics reasoning. Paper presented at the FIRE: Forum for International Research in Education, 4, 67-87. https:/ / doi.org/10.18275/ fire201704011120

Boslaugh, S. (2007). Secondary data sources for public health: A practical guide: Cambridge University Press. https:/ / doi.org/10.1017/CBO9780511618802

Brady, K. (2016, October 12). German Education Minister Unveils 5-Billion-Euro 'DigitalPact' for 40,000 schools. Deutsche Welle. Retrieved from https://www.dw.com/en/german-educationminister-unveils-5-billion-euro-digital-pact-for40000-schools/a-36023544

Bulut, O., \& Cutumisu, M. (2017). When technology does not add up: ICT use negatively predicts mathematics and science achievement for Finnish and Turkish students in PISA 2012. Paper presented at the EdMedia+ Innovate Learning. Retrieved from https://sites. ualberta.ca/ cutumisu/publications/2017/2017E dMedia_BulutCutumisu.pdf
Bundesministerium für Bildung und Forschung. (2016). Bildungsoffensive für die digitale Wissensgesellschaft: Strategie des Bundesministeriums für Bildung und Forschung. Retrieved from https://www.bmbf.de/ files/Bildungsoffensive_fuer_die_digitale_Wissen sgesellschaft.pdf

Comi, S. L., Argentin, G., Gui, M., Origo, F., \& Pagani, L. (2017). Is it the way they use it? Teachers, ICT and student achievement. Economics of Education Review, 56, 24-39. https://doi.org/10.1016/j.econedurev. 2016.11.007

Creemers, B. P. (1994). Effective instruction: An empirical basis for a theory of educational effectiveness. In Advances in school effectiveness research and practice (pp. 189-205): Elsevier. https:/ / doi.org/10.1016/B978-0-08-0423920.50014-0

Cresswell, J., \& Plano Clark, V. (2011). Designing and conducting mixed method research. 2nd Sage. Thousand Oaks, CA.

Drossel, K., \& Eickelmann, B. (2017). Teachers' participation in professional development concerning the implementation of new technologies in class: a latent class analysis of teachers and the relationship with the use of computers, ICT self-efficacy and emphasis on teaching ICT skills. Large-scale Assessments in Education, 5(1), 1-13. https://doi.org/10.1186/ s40536-017-0053-7

Eickelmann, B., Drossel, K., Wendt, H., \& Bos, W. (2012). ICT-use in primary schools and children's mathematics achievement-a multi-level approach to compare educational systems through an international lens with TIMSS data. Paper presented at the Joint AARE APERA International Conference, WERA focal meeting, Sydney. Retrieved from https://kw.unipaderborn.de/fileadmin/fakultaet/Institute/erzie hungswissenschaft/Schulpaedagogik/PDF/WER A_2012_Eickelmann_et_al..pdf

Eickelmann, B., Lorenz, R., \& Endberg, M. (2016). Die eingeschätzte Relevanz der Phasen der Lehrerausbildung hinsichtlich der Vermittlung didaktischer und methodischer Kompetenzen von Lehrpersonen für den schulischen Einsatz digitaler Medien in Deutschland und im Bundesländervergleich. In W. Bos, R. Lorenz, M. Endberg, B. Eickelmann, R. Kammerl, \& S. Welling (Eds.), Schule digital-der Länderindikator 2016. Kompetenzen von Lehrpersonen der Sekundarstufe I im Umgang mit digitalen Medien im Bundesländervergleich (pp. 149-182). Münster: Waxmann.

Falck, O., Mang, C., \& Woessmann, L. (2018). Virtually no effect? Different uses of classroom computers and their effect on student achievement. Oxford 
Bulletin of Economics and Statistics, 80(1), 1-38. https:/ / doi.org/10.1111/obes.12192

Fraillon, J., Ainley, J., Schulz, W., Friedman, T., \& Gebhardt, E. (2014). Students' use of and engagement with ICT at home and school. In Preparing for life in a digital age (pp. 125-166): Springer. https://doi.org/10.1007/978-3-31914222-7_6

Garson, G. D. (2013). Introductory guide to HLM with HLM 7 software. Hierarchical linear modeling: Guide and applications, 55-96. https://doi.org/10.4135/ 9781483384450.n3

Geesa, R. L., Izci, B., Song, H., \& Chen, S. (2019). Exploring factors of home resources and attitudes towards mathematics in mathematics achievement in South Korea, Turkey, and the United States. EURASIA Journal of Mathematics, Science and Technology Education, 15(9), em1751. https:/ / doi.org/10.29333/ejmste/108487

Güzeller, C. O., \& Akin, A. (2014). Relationship between ICT variables and mathematics achievement based on PISA 2006 database: International evidence. Turkish Online Journal of Educational TechnologyTOJET, 13, 184-192. https://files.eric.ed.gov/ fulltext/EJ1018171.pdf

Heinz, J. (2016). Digital skills and the influence of students' socio-economic background. An exploratory study in German elementary schools. Italian Journal of Sociology of Education, 8(2). https://doi.org/10.14658/pupj-ijse-2016-2-9

Hsieh, H.-F., \& Shannon, S. E. (2005). Three approaches to qualitative content analysis. Qualitative health research, 15(9), 1277-1288. https:/ / doi.org/10.1177/ 1049732305276687

Hu, X., Gong, Y., Lai, C., \& Leung, F. K. (2018). The relationship between ICT and student literacy in mathematics, reading, and science across 44 countries: A multilevel analysis. Computers $\mathcal{E}$ Education, 125, 1-13. https://doi.org/10.1016/ j.compedu.2018.05.021

IEA. (2019). TIMSS 2015: Grade 4 SPSS data and documentation. Chestnut Hill: TIMSS \& PIRLS International Study Center, Lynch School of Education, Boston College and International Association for the Evaluation of Educational Achievement (IEA). Retrieved from https:/ / www. iea.nl/repository/studies/timss-20151

Johansone, I. (2016). Survey Operations Procedures in TIMSS 2015. In M. O, Martin, I. V. S, Mullis \& M, Hooper, (Eds.), Methods and Procedures in TIMSS 2015 (pp. 6.1 - 6.22). Chestnut Hill, MA: TIMSS \& PIRLS International Study Center, Lynch School of Education, Boston College and International Association for the Evaluation of Educational Achievement (IEA). Retrieved from https:// timssandpirls.bc.edu/publications / timss /2015methods/T15_MP_Chap6_Survey_Operations.pdf

Kadijevich, D. M. (2015). A dataset from TIMSS to examine the relationship between computer use and mathematics achievement. British Journal of Educational Technology, 46(5), 984-987. https:/ / doi.org/10.1111/bjet.12309

Kim, S. (2018). ICT and the UN's sustainable development goal for education: Using ICT to boost the math performance of immigrant youths in the US. Sustainability, 10(12), 4584. https:/ / doi.org/10.3390/su10124584

Kraus, J. (2015, February 25). Lehrerverband warnt vor "totaler Zwangsdigitalisierung". Deutschlandfunk Kultur. Retrieved from https://translate.google. com/translate?hl=en\&sl=de\&u=https:/ / www.de utschlandfunkkultur.de/schule-lehrerverbandwarnt-vor-totaler-zwangsdigitalisierung.1008.de. html\%3Fdram:article_id\%3D312601\&prev=search

Kreijger, G. (2017, January 15). In German schools, tech arrives at snail's pace. Handelsblatt Retrieved on 25 April 2019 from https://www.handelsblatt.com/ today / politics / uphill-battle-in-german-schoolstech-arrives-at-snails-pace/23565294.html?ticket= ST-1262843-KSIQYHTKYU5CcW5yMeRM-ap2

Kruger, G. M. (2018). The relationship between investment in ICT and mathematics achievement (Unpublished doctoral dissertation, University of Pretoria, Pretoria). Retrieved from https:/ / repository.up.ac. za/bitstream/handle/2263/67752/Kruger_Relatio nship_2018.pdf?sequence $=1$ \&isAllowed $=y$

Kultusministerkonferenz. (2016). Bildung in der digitalen Welt Bildung in der digitalen Welt, Strategie der Kultusministerkonferenz. Retrieved on 13 March 2019 from https://www.kmk.org/aktuelles/ thema-2016-bildung-in-der-digitalen-welt.html

LaRoche, S., Joncas, M., \& Foy, P. (2016). Sample Design in TIMSS 2015. In M. O, Martin, I. V. S, Mullis \& M, Hooper, (Eds.), Methods and Procedures in TIMSS 2015 (pp. 3.1 - 3.37). Chestnut Hill, MA: TIMSS \& PIRLS International Study Center, Lynch School of Education, Boston College and International Association for the Evaluation of Educational Achievement (IEA). https:/ / timssandpirls.bc.edu/ publications/timss/2015-methods/chapter-3.html

Meggiolaro, S. (2018). Information and communication technologies use, gender and mathematics achievement: evidence from Italy. Social Psychology of Education, 21(2), 497-516. https://doi.org/ $10.1007 /$ s11218-017-9425-7

Mullis, I. V. S., Martin, M. O., Foy, P., \& Hooper, M. (2016). TIMSS 2015 International results in mathematics. Chestnut Hill, MA: TIMSS \& PIRLS International Study Center, Lynch School of Education, Boston College and International 
Association for the Evaluation of Educational Achievement (IEA). Retrieved from http://timss andpirls.bc.edu/timss2015/international-results /

OECD. (2014). Measuring Innovation in Education: A New Perspective, Educational Research and Innovation. Paris, France: OECD Publishing. https://doi.org/ 10.1787/9789264215696-en

OECD. (2016). PISA 2015 Results (Volume I): Excellence and Equity in Education. Paris, France: OECD Publishing.

https: / / doi.org/10.1787/9789264266490-en

Petko, D., Cantieni, A., \& Prasse, D. (2017). Perceived quality of educational technology matters: A secondary analysis of students' ICT use, ICTrelated attitudes, and PISA 2012 test scores. Journal of Educational Computing Research, 54(8), 1070-1091. https: / / doi.org/10.1177/0735633116649373

Skryabin, M., Zhang, J., Liu, L., \& Zhang, D. (2015). How the ICT development level and usage influence student achievement in reading, mathematics, and science. Computers $\mathcal{E}$ Education, 85, 49-58. https:// doi.org/10.1016/j.compedu.2015.02.004

Spitzer, M. (2012). Digitale Demenz: Wie wir uns und unsere Kinder um den Verstand bringen: Droemer Knaur. Munich.

Spitzer, M. (2016, December 15). Digital dementia, dott. Manfred spritzer. Retrieved from https://www. youtube.com/watch? $\mathrm{v}=$ Pgp-0MyWtJQ

Topçu, M. S., Erbilgin, E., \& Arikan, S. (2016). Factors predicting Turkish and Korean students' science and mathematics achievement in TIMSS 2011. EURASIA Journal of Mathematics, Science and Technology Education, 12(7), 1711-1737. https:/ / doi.org/10.12973/eurasia.2016.1530a

Üing, S. (2013, May 20). German schools reluctant to go 'digital'. Retrieved from https://www.dw.com/ en/german-schools-reluctant-to-go-digital/a16785880
Venneman, M., Eickelmann, B., \& Wendt, H. (2018). ICT use in primary mathematics education - Does the school context matter? In R. Walker, \& S. Bedford (Eds.), European Educational Research Association 2018: Inclusion and Exclusion, Resources for Educational Research (pp. 25-37). Free University Bolzano, Bolzano. Retrieved from https://web cache.googleusercontent.com/search?q=cache:Ec HihUB3CiAJ:https:/ / eera-ecer.de/ecerprogrammes/conference/23/contribution/46458/ $+\& \mathrm{~cd}=7 \& \mathrm{hl}=\mathrm{en} \& \mathrm{ct}=\mathrm{clnk} \& \mathrm{gl}=\mathrm{za}$

Visser, M., Juan, A., \& Feza, N. (2015). Home and school resources as predictors of mathematics performance in South Africa. South African Journal of Education, 35(1). https://doi.org/10.15700/ 201503062354

Woltam, H., Feldstain, A., MacKay, J., \& Rocchi, M. (2012). An introduction to hierarchical linear modelling. Tutorials in Quantitative Methods for Psychology, 8(1), 52-69. https://doi.org/10.20982/ tqmp.08.1.p052

$\mathrm{Xu}$, J. (2015). Investigating factors that influence conventional distraction and tech-related distraction in math homework. Computers $\mathcal{E}$ Education, 81, 304-314. https://doi.org/10.1016/ j.compedu.2014.10.024

Zhang, D., \& Liu, L. (2016). How does ICT use influence students' achievements in math and science over time? Evidence from PISA 2000 to 2012. EURASIA Journal of Mathematics, Science and Technology Education, 12(9), 2431-2449. https://doi.org/ 10.12973/eurasia.2016.1297a

Zuzovsky, R. (2013). What works where? The relationship between instructional variables and schools' mean scores in mathematics and science in low-, medium-, and high-achieving countries. Large-scale Assessments in Education, 1(1), 2. https:/ / doi.org/10.1186/2196-0739-1-2 


\section{APPENDIX A}

\section{The Relationship between Integrating Educational Technology in Mathematics Education and Learner Achievements}

As explained earlier HLM was used to determine the relationship between using educational technology in mathematics education and learner achievements. In order to use the HLM software, complete datasets must be available, i.e. there must be no missing values. The decision was made to employ the maximum likelihood Expectation Maximization (EM) algorithm to replace the missing values. Three HLM analyses were created. Initially, the null model without any variables was created (see Table 5). This model was required to determine the need for using HLM and to calculate the intraclass correlation coefficient (ICC), which shows the variance in the mathematics achievement (outcome variable) between schools (level-2) (Garson, 2013). The variance at school-level is considerably different from zero because the p-value is less than 0.05 ( $p$-value $<0.001$ ), which justified the use of HLM in this study.

Table 5. The null model of Germany

\begin{tabular}{lccccc}
\hline & Standard Deviation & Variance Component & df & Chi-square & p-value \\
\hline INTRCPT1, u0 & 26.92 & 725.20 & 203 & 974.49 & $0.000^{*}$ \\
Level-1, r & 59.33 & 3520.23 & & \\
\hline
\end{tabular}

* Significant at a $5 \%$ level of significance

Thereafter, the ICC was calculated to determine the variance as explained in Woltam, Feldstain, MacKay, and Rocchi (2012): ICC $=725.20$ / (3520.23+726.02), resulting in an ICC of 0.170 . This suggests that only $17.07 \%$ of the variance of mathematics performance is at school-level and, consequently, $82.93 \%$ is at learner-level. Subsequently, we created the full model, which included both learner and school variables (see Table 6). This step was important since it could show the relationships between the variables and the learners' mathematics performance. The variance at school-level is 418.36 , representing $12.22 \%$ of the overall variance. Consequently, the variance at learner-level is 3001.31 , representing $87.78 \%$ of the total variance. Furthermore, the variance at school-level is significantly different from zero, because the $\mathrm{p}$-value is less than 0.05 ( $\mathrm{p}$-value $<0.001$ ).

Table 6. The full model of Germany

\begin{tabular}{lccccc}
\hline & Standard Deviation & Variance Component & df & Chi-square & p-value \\
\hline INTRCPT1, u0 & 20.45 & 418.36 & 183 & 756.62 & $0.000^{*}$ \\
Level-1, r & 54.78 & 3001.31 & & & \\
\hline
\end{tabular}

* Significant at a $5 \%$ level of significance

Lastly, the parsimonious model was created (see Table 7). This model was created by eliminating all insignificant ( $p$-value $>0.05)$ variables individually, till only significant $(p$-value $<0.05)$ variables remained.

Table 7. The parsimonious model

\begin{tabular}{lccccc}
\hline & Standard Deviation & Variance Component & df & Chi-square & p-value \\
\hline INTRCPT1, u0 & 22.81 & 520.59 & 202 & 853.80 & $0.000 *$ \\
Level-1, r & 54.82 & 3005.70 & & & \\
\hline
\end{tabular}

* Significant at a $5 \%$ level of significance

The variance at school-level is 520.59 showing $2 \%$ of the total variance. Thus, the variance at learner-level is 3005.70 representing $98 \%$ of the entire variance. Furthermore, the variance at the school-level is significantly different from zero because the $\mathrm{p}$-value is less than 0.05 ( $\mathrm{p}$-value $<0.001$ ). The average reliability estimate is 0.73 , indicating that sample averages reflected the true school means.

\section{http://www.ejmste.com}

